\title{
Comparison of Functional Properties between Native and Chemically Modified Starches from Acha (Digitaria Stapf) Grains
}

\author{
B. I. Olu-Owolabi ${ }^{1}$, O. O. Olayinka ${ }^{2 *}$, A. A. Adegbemile ${ }^{1}$, K. O. Adebowale ${ }^{1}$ \\ ${ }^{1}$ Department of Chemistry, University of Ibadan, Ibadan, Nigeria; ${ }^{2}$ Department of Environmental Management and Toxicology, Col- \\ lege of Environmental Resources and Management, Federal University of Agriculture, Abeokuta, Nigeria. \\ Email: iromidayobamidele@yahoo.co.uk, fummy2favour@yahoo.com.ph, adegbemile2002@yahoo.com, \\ adebowale2003@yahoo.com
}

Received December $31^{\text {st }}$, 2010; revised February $7^{\text {th }}$, 2013; accepted February $14^{\text {th }}, 2013$

Copyright (C) 2014 B. I. Olu-Owolabi et al. This is an open access article distributed under the Creative Commons Attribution License, which permits unrestricted use, distribution, and reproduction in any medium, provided the original work is properly cited. In accordance of the Creative Commons Attribution License all Copyrights (C) 2014 are reserved for SCIRP and the owner of the intellectual property B. I. Olu-Owolabi et al. All Copyright (c) 2014 are guarded by law and by SCIRP as a guardian.

\section{ABSTRACT}

Acha grain (Digitariaexilis) starch was isolated and subjected to chemical modifications by acetylation, benzylation, succinylation, carboxymethylation and acid-thining. Functional properties (swelling, solubility, gelation, oil and water absorption capacities, alkaline water retention) and rheological properties of the native and modified starches were determined. Swelling power and solubility of the starch samples increased with increase in temperature. Swelling power and solubility were $\mathrm{pH}$ dependent, with maximum values obtained at pH 12 in both native and modified starches. Increasing degree of alkalinity increased both solubility and swelling capacity. Water absorption capacities of chemically modified starches decreased, but acetylated starch, ATAS showed higher value compared to the native and also chemically modified starches improved oil absorption capacity of the native starch. The modified starches showed increase in alkaline water retention. Gelation studies revealed that ACAS had higher LGC than the native while some chemically modified starches did not alter the gelation capacity of the native starch except for BAS and ACAS with LGC of $10 \%$ and $16 \% \mathrm{v} / \mathrm{w}$. There were significant differences in functional properties between native and chemically modified starches from acha, so chemical modification improved functional properties. Chemical modifications increased pasting temperature except for ATAS and BAS. Set-back values were reduced after modifications, indicating that modification would minimize starch retrogradation.

\section{KEYWORDS}

(Digitariaexilis Stafp); Functional Properties; Chemical Modification; Rheological Properties; Starches

\section{Introduction}

Starch is the major raw material in the food industry because of its good thickening and gelling properties, which make it an excellent ingredient for the manufacture of various food products [1]. Native starches, irrespective of their sources are undesirable for many applications because of their inability to withstand processing conditions, so there is a need to improve desirable functional properties. In order to meet the requirements of

${ }^{*}$ Corresponding author. specific industrial processes, starches are modified chemically by degradation, substitution or cross-bonding. Chemical modifications improved the functional characteristics of the starch and tailored it to specific food applications. They also offer a number of desirable properties such as high viscosity, better thickening power, low gelatinization and retrogradation. Chemical modification is generally achieved through derivatization such as etherification, esterification, cross-linking and acid hydrolysis [2]. In acetylation, hydrophilic hydroxyl groups are substituted with hydrophobic acetyl groups. It makes 
starch more hydrophobic and prevents the formation of hydrogen bonding between hydroxyl groups and water molecules. Since an aqueous starch dispersion has the tendency to increase in viscosity on cooling and finally gel is related to the association of amylose molecules. The acetylation treatment retarding or eliminating retrogradation will affect stabilization of the starch sol.

In acid modification, the hydroxonium ion attacks the glycosidic oxygen atom and hydrolyses the glycosidic linkage. An acid acts on the surface of the starch granule first before it gradually enters the inner region. It changes the physicochemical properties of starch without destroying its granule structure and the properties of acidthinned starches differ according to their origin [3]. Effect of different acids $\left(\mathrm{HCl}, \mathrm{HNO}_{3}, \mathrm{H}_{2} \mathrm{SO}_{4}\right.$, and $\left.\mathrm{H}_{3} \mathrm{PO}_{4}\right)$ used in the preparation under similar conditions of treatment on molecular weight, alkali fluidity number, iodine binding capacity and intrinsic viscosity of various starches has also been studied [4]. Succinylation imparts a hydrophilic character to starch, and it is known to weaken the internal bonding that holds the granules together [5]. It modifies its physicochemical properties, which widens its range of applications in food and nonfood industries like pharmaceuticals, paper and textile industries. Also, the hydrophobic benzyl groups weakened the internal hydrogen bonding and helped starch swell at relatively low temperature.

Acha (Digitariaexilis) is an underutilized African cereal grain and also is a member of the grass family. Gramineae (Poaceae) belongs to the same subfamily with maize, sorghum, and pearl millet. However, traditional cereals, acha (Digitariaexilis Stapf) and iburu (D. iburua Stapf) which are also called fonio [6], fundi, findi, hungry rice, and Asian millet [7] have received increasing attention in research and development since the last review ([8-15]). Such attention is seen in the European Fonio project-a cereal believed to be a healthy and cheap addition to European diets, while at the same time generating incomes for local producers in Africa [16]. It is possible that acha is potentially important source of nutraceuticals such as antioxidant phenolics and cholesterol-lowering waxes. It was previously reported [17] that acha helped diabetic patients in parts of West Africa. Consumption of the grain as whole grain makes it an excellent source of dietary fibre and associated nutraceutical benefits of whole grain suitable for the health conscious and for obesity and diseases, such as diabetes. Acha is nutritious and its grains are rich in methionine [18], an amino acid vital to human health and deficient in major cereals. It contains a high percentage of starch $(60 \%$ - 80\%). Although there is an abundance of starch reserves in many tropical plants, attention is focused primarily on tubers and root crops for starch production.
Consequently, there is an over-exploitation of these crops. There is therefore the need for the identification of underutilized starch sources in order to supplement the available starches. Acha grain could therefore serve as a potential substitute for the over-exploited starch sources. Hence, it becomes pertinent to study the functional properties of acha grain starch to provide data which would be useful for food industries.

\section{Materials and Methods}

\subsection{Samples}

Acha grains were purchased at a local market in Jos, Plateau state, Nigeria.

Defected grains and stones were handpicked. All chemicals used were of Analar grade.

\subsection{Isolation of Starch}

One kg of the sample was soaked in 40 litres of distilled water and the $\mathrm{pH}$ was adjusted to 8.0 using solution of $\mathrm{NaOH}(0.2 \% \mathrm{w} / \mathrm{v})$ at $4^{\circ} \mathrm{C}$ for $12 \mathrm{~h}$. It was then manually stirred for 30 minutes. The grains were screened and washed with distilled water until they were unpigmented. The grains were pulverized for 30 min using warring blend (Braun Multimix de luxe MX40, type 2291). The slurry obtained after blending was re-suspended in $50 \mathrm{ml}$ of distilled water and the $\mathrm{pH}$ was adjusted to 8.0, using $0.5 \mathrm{M} \mathrm{NaOH}$ solution. While keeping the $\mathrm{pH}$ at 8.0 - 8.5, the mixture was stirred manually for $30 \mathrm{~min}$. The suspension obtained was screened through mesh using 75 $\mu \mathrm{m}$ and $80 \mu \mathrm{m}$ sieve and centrifuged for 30 minutes at 10.000 g (Type GLC-1 Ivan Sovall Inc., USA) and washed with distilled water twice before air-drying for 48 hours at $30^{\circ} \mathrm{C} \pm 2^{\circ} \mathrm{C}$. The starch obtained (Analysis: yield, $50.60 \%$; moisture content, $12.30 \%$; protein, $1.02 \%$; ash, $0.95 \%$; fat, $0.35 \%$; crude fibre, $1.18 \%$; carbohydrate, $81.20 \%$. It was stored in an enclosed plastic bottle until use.

Proximate analysis for moisture, protein $(\mathrm{N} \times 6.25)$ ash content, fat, crude fiber and carbohydrate was carried out according to the methods described in [19].

\subsection{Chemical Modifications}

\subsubsection{Acid Thinned Starch}

The method of [4] was employed in preparation of acidified sorghum starch. $200 \mathrm{~g}$ (dry basis) of the starch sample was hydrolyzed by suspension in $600 \mathrm{ml}$ of $6 \%(\mathrm{w} / \mathrm{v})$ $\mathrm{HCl}$. Solution at $50^{\circ} \mathrm{C}$ for 24 hours in water bath or hot plate.

The slurry was stirred frequently during the treatment period. At the end of the time the reaction was stopped by neutralization with $10 \%(\mathrm{w} / \mathrm{v}) \mathrm{NaOH}$ solution. The 
suspension was then washed three times with distilled water repeatedly until the filtrate was free from respective ions. The wet acid modified starch was air-dried in the air for $48 \mathrm{~h}$ at $30^{\circ} \mathrm{C} \pm 2.0^{\circ} \mathrm{C}$. The dried powder was finally sieved through a 100 -mesh sifter to obtain acid-modified starch powder.

\subsubsection{Acetylated Starch}

The method of [20] was used for starch acetylation. 100 $\mathrm{g}$ of starch were dispersed in $500 \mathrm{ml}$ of distilled water; it was magnetically stirred for 20 minutes. The $\mathrm{pH}$ of the slurry obtained was adjusted to 8.0 using $1 \mathrm{M}$ of $\mathrm{NaOH}$. $10.2 \mathrm{~g}$ acetic anhydride was added over a period of one hour while maintaining a $\mathrm{pH}$ range of 8.0 - 8.5. The reaction proceeded for 5 minutes after the addition of acetic anhydride. The $\mathrm{pH}$ of the slurry was adjusted to 4.5 using $0.5 \mathrm{M} \mathrm{HCl}$. It was filtered, washed for four times with distilled water and air-dried of $30^{\circ} \mathrm{C} \pm 2.0^{\circ} \mathrm{C}$ for 48 hours.

\section{Determination of degree substitution of acetylated} starch

The determination of the degree of substitution (D.S) of the acetylated starch was carried out by the procedure of [21]. $5 \mathrm{~g}$ of the acetylated starch was dispersed in $75 \%$ aqueous ethanol and warmed for 30 minutes in water bath at $50^{\circ} \mathrm{C}$. This was cooled to room temperatures and $25 \mathrm{ml}$ of $1.0 \mathrm{M} \mathrm{NaOH}$ solution was added. Using the purified starch instead of the acetylated starch, a blank determination was carried out alongside that of the acetylated starch. The two flasks were Stoppard and allowed to stand for 72 hours at room temperature and occasionally swirled. Excess $\mathrm{NaOH}$ was then back titrated with 2.0 M HCl using methyl orange as indicator and the flask were allowed to stand at room temperature for 2 hours, and the titration completed.

$$
\begin{gathered}
\% \text { Acetyl }=\frac{(\text { Blank }- \text { sample }) \mathrm{ml} \times \mathrm{M}_{\mathrm{HCl}} \times 0.43 \times 100}{\text { Weight of sample }} \\
\text { D.S. }=\frac{162 \times \% \text { Acetyl }}{4300-(42 \times \% \text { Acetyl })}
\end{gathered}
$$

\subsubsection{Preparation of Succinylated Starch}

Succinylated starch was prepared by reacting native starches with succinic anhydride according to the method of [22] with some modifications. Starch (20 g) was dissolved in a sodium carbonate solution (1 g Sodium Carbonate in $30 \mathrm{ml}$ distilled water), mixed with $1 \mathrm{~g}$ succinic anhydride and the succinylation was carried out for 14 hours or more at room temperature with stirring. The $\mathrm{pH}$ of the resultant solution was adjusted to 7.0 with $0.2 \mathrm{~N}$ $\mathrm{HCl}$, filtered through Whatman No. 4 filter paper, washed with ethanol and then dried in an oven set at $40^{\circ} \mathrm{C} \pm 1^{\circ} \mathrm{C}$.

\section{Determination of degree of substitution of succi- nated starch}

Succinyl content and the degree of substitution (D.S.) of the starches were determined according to [23].

$$
\mathrm{DS}=\frac{162 \times \% \text { Succinylation }}{10,000-(99 \times \% \text { Succinylation })}
$$

where, $162=$ molecular weight of glucose unit, 10,000 = $100 \times$ molecular weight of succinyl group, $99=$ molecular weight of succinyl group.

\subsubsection{Benzylated Starch}

Benzyl was prepared by the method of [24] with some modifications. Anhydrous $\mathrm{Na}_{2} \mathrm{SO}_{4}(100 \mathrm{~g})$ and $\mathrm{NaOH}(3$ - $8 \mathrm{~g}$ ) were dissolved in150 $\mathrm{ml}$ of warm distilled water $\left(50^{\circ} \mathrm{C}\right)$. Starch of $100 \mathrm{~g}$, (dry weight) and benzyl chloride ( $5 \%-50 \%$, based on starch) were reacted by stirring at $65^{\circ} \mathrm{C}$ for 14 hours. Concentrated $\mathrm{Na}_{2} \mathrm{SO}_{4}$ in the solution prevented the alkali from making the starch granules swell during the reaction. The reaction was stopped by neutralizing the mixture to $\mathrm{pH} 6$ with $1 \mathrm{~N} \mathrm{HCl}$. The starch was filtered, and washed five times with $150 \mathrm{ml}$ distilled water and finally with $95 \%$ ethanol $(150 \mathrm{ml})$. The starch residue was then dried overnight in a $40^{\circ} \mathrm{C}$ convention oven.

\subsubsection{Carboxymethylated Starch}

The method of [25] was used. 20.0 g starch (dry basis) was weighed into large heating tubes, followed by $10.0 \mathrm{~g}$ Sodium monochloroacetate and 4.48 g Sodium Hydroxide and mixture was thoroughly homogenized. $200 \mathrm{ml}$ of appropriate propanol was added. This was thoroughly stirred and set up in thermostatic Clifton water bath at $45^{\circ} \mathrm{C}$ for 1 hour. The mixture was occasionally stirred. At the end of the reaction the sample was removed and precipitated. The precipitated was washed with excess $80 \%$ aqueous methanol until free from unreacted reagents. The modified starch sample was dried in the oven at $100^{\circ} \mathrm{C}$ for 1 hour and stored.

\section{Determination of the degree of carboxymethyla- tion}

2 gram of the carboxymethyl starch was converted to the $\mathrm{H}$-form by treating with excess $0.1 \mathrm{M}$ aqueous $80 \%$ methanolic $\mathrm{HCl}$ in a $100 \mathrm{ml}$ beaker with occasional stirring for 1 hour. This was followed by filtering and washing under suction in a sintered glass funnel with aqueous $80 \%$ methanol until free from acid (filtrate had no effect on blue litmus paper). The resulting sample was dried in the oven at $100^{\circ} \mathrm{C}$ for 1 hour and cooled in a dessicator. 0.25 gram of the sample was weighed into a $250 \mathrm{ml}$ conical flask and $100 \mathrm{ml}$ distilled water added, followed by $10 \mathrm{ml}$ of $0.107 \mathrm{M} \mathrm{NaOH}$ solution. This was heated over a boiling water bath for about 20 minutes 
when a clear solution results. The hot solution was titrated with standard $0.054 \mathrm{M} \mathrm{HCl}$ to a phenolphthalein endpoint. Native starch was similarly processed as above and used as blank.

$$
\begin{aligned}
& \text { \% carbony } 1=\frac{\text { titre for sample }}{\text { Weight of sample }} \\
& -\frac{(\text { titre for native starch }) \times \mathrm{M} \mathrm{NaOH} \times 0.045 \times 100}{\text { Weight of native starch }} \\
& \quad \text { Degree of carboxymethylation }(\text { D.C }) \\
& \quad=\frac{162 \times \% \text { carbony } 1}{4500-58 \times \% \text { carbony } 1 \mathrm{~s}}
\end{aligned}
$$

where, 162 = molecular weight of glucose unit.

\subsection{Effect of Temperature on Swelling Power}

[26] was employed for the determination of the effect of temperature on the starch solubility and swelling. $1 \mathrm{~g}$ of the starch sample was accurately weighed and quantitatively transferred into a clean dried test tube and weighed $\left(w_{1}\right)$. The starch was then dispersed in $50 \mathrm{~cm}^{3}$ of distilled water using stirrer. The slurry obtained was heated for 30 minutes at various temperatures from $60^{\circ} \mathrm{C}-90^{\circ} \mathrm{C}$ respectively. The mixture was cooled to room temperature and centrifuged for $15 \mathrm{~min}$ at $3000 \mathrm{rpm}$. Aliquots $(5 \mathrm{ml})$ of the supernatant were dried to a constant weight at $110^{\circ} \mathrm{C}$

Solubility was calculated as g per $100 \mathrm{~g}$ of starch on dry weight basis. The residue obtained from the above experiment after centrifugation, with the water it retained was quantitatively transferred to the clean dried test tube used earlier and weighed $\left(w_{2}\right)$.

$$
\text { Percentage swelling of starch }=\frac{w_{2}-w_{1}}{\text { Weight of starch }} \times 100
$$

\subsection{Oil and Water Absorption Capacities}

The method of [27] was employed to determine the oil and water absorption capacities of the starch.

\subsection{Gelation Studies}

The gelation properties of the starch were determined as described by [28].

\subsection{Alkaline Water Retention}

About $1.0 \mathrm{~g}$ of each sample was quantitatively transferred into a test tube previously weighed $\left(W_{1}\right), 5.0 \mathrm{ml}$ of $0.1 \mathrm{M} \mathrm{NaHCO}_{3}$ was added and mixed for $30 \mathrm{~s}$ in a fisher vortex genie $2^{\mathrm{TM}}$ mixer. The sample was then allowed to stand at $30^{\circ} \mathrm{C} \pm 2^{\circ} \mathrm{C}$ for $20 \mathrm{~min}$, centrifuged $(200 \mathrm{rpm}$, $150 \mathrm{~min}$ ) and drained for $10 \mathrm{~min}$ at an angle $10^{\circ} \mathrm{C}-15^{\circ} \mathrm{C}$ to the horizontal. Test tube with the content was then weighed $\left(W_{2}\right)$ and the alkaline water retention calculated as follows: alkaline water retention capacity $(\mathrm{g} / \mathrm{g})$ of sample $W_{2}-W_{1}$.

\subsection{Pasting Properties}

Rapid Visco-Analyser Model 3D (RVA: Newport Scientific Pty. Ltd., Warriewood, Australia) was used to determine the pasting properties of the starches $10 \%$ suspension ( $3 \mathrm{~g}$ in $30 \mathrm{ml}$ of distilled water). The slurry underwent a controlled heating-and-cooling cycle under constant shear where it was held at $50^{\circ} \mathrm{C}$ for $1 \mathrm{~min}$, heated from $50^{\circ} \mathrm{C}$ to $95^{\circ} \mathrm{C}$ at $12^{\circ} \mathrm{C} / \mathrm{min}$ and the sample held at $95^{\circ} \mathrm{C}$ for $2.5 \mathrm{~min}$ and held at $50^{\circ} \mathrm{C}$ for $5 \mathrm{~min}$.

\subsection{Statistical Analysis}

All determinations were done in triplicate, and the means were then calculated. Data were assessed by analysis of variance (ANOVA; Snedcor and Cochran, 1987) and where significant differences were found, the means were separated by Duncan's multiple range test with a probability of $\mathrm{p} \leq 0.05$ (Duncan, 1955). Data analysis software used was SPSS.

\section{Results and Discussion}

\subsection{Proximate Composition}

The result of the chemical composition is presented in Table 1. The moisture content of the starches ranged between $7.96 \%$ and $13.50 \%$. Following modification, the acetylated (ATAS), benzylated (BAS), carboxymethylated (CAS), succinylated (SAS) and acidified (ACAS) starches reduced moisture content compared to native starch, while the least moisture level was observed in BAS. These low values of moisture contents are advantageous in terms of shelf life. Crude fibre and fat content of the native starch reduced following modifications. This agreed with the [5]. The protein content of the starches was between $0.72 \%$ and $1.05 \%$. These low values showed the purity of the starches as indicated by the low nitrogen and low ash levels [29]. All forms of modification reduced protein content and the least protein content was observed in SAS, while the highest was observed in acid thinned starch. This agreed with the observation of [30].

\subsection{Effect of Temperature on Swelling Power and Solubility}

Swelling of acha starch and the modified derivatives were temperature dependent (Table 2). Swelling power increased as temperature increased in native and modified starches. This result agrees with the observations of 
Table 1. Chemical composition of native and chemically modified acha starches.

\begin{tabular}{cccccccc}
\hline Sample & Moisture (\%) & Ash (\%) & Crude Fibre (\%) & Fat (\%) & Protein (\%) & Amylose (\%) & CHO (\%) \\
\hline ANS & $13.50 \pm 0.02^{\mathrm{f}}$ & $1.18 \pm 0.01^{\mathrm{e}}$ & $1.08 \pm 0.03^{\mathrm{f}}$ & $0.36 \pm 0.01^{\mathrm{d}}$ & $1.05 \pm 0.00^{\mathrm{d}}$ & $25.55 \pm 1.00^{\mathrm{b}}$ & 82.83 \\
ACAS & $7.96 \pm 0.05^{\mathrm{b}}$ & $0.69 \pm 0.02^{\mathrm{a}}$ & $0.78 \pm 0.05^{\mathrm{b}}$ & $0.31 \pm 0.04^{\mathrm{bcd}}$ & $1.02 \pm 0.04^{\mathrm{d}}$ & $20.55 \pm 1.20^{\mathrm{a}}$ & 89.24 \\
BAS & $7.88 \pm 0.02^{\mathrm{a}}$ & $0.82 \pm 0.03^{\mathrm{b}}$ & $1.00 \pm 0.01^{\mathrm{e}}$ & $0.28 \pm 0.04^{\mathrm{bc}}$ & $0.80 \pm 0.05^{\mathrm{b}}$ & $21.66 \pm 1.20^{\mathrm{a}}$ & 89.22 \\
ATAS & $8.45 \pm 0.01^{\mathrm{d}}$ & $1.00 \pm 0.03^{\mathrm{d}}$ & $0.60 \pm 0.02^{\mathrm{a}}$ & $0.34 \pm 0.03^{\mathrm{cd}}$ & $0.91 \pm 0.03^{\mathrm{c}}$ & $25.85 \pm 1.10^{\mathrm{b}}$ & 88.70 \\
SAS & $8.05 \pm 0.04^{\mathrm{c}}$ & $1.03 \pm 0.04^{\mathrm{d}}$ & $0.90 \pm 0.02^{\mathrm{d}}$ & $0.18 \pm 0.01^{\mathrm{a}}$ & $0.72 \pm 0.02^{\mathrm{a}}$ & $24.42 \pm 1.00^{\mathrm{b}}$ & 89.12 \\
CAS & $8.65 \pm 0.03^{\mathrm{e}}$ & $0.91 \pm 0.02^{\mathrm{c}}$ & $0.85 \pm 0.01^{\mathrm{c}}$ & $0.27 \pm 0.02^{\mathrm{b}}$ & $1.00 \pm 0.01^{\mathrm{d}}$ & $21.25 \pm 1.40^{\mathrm{a}}$ & 88.32 \\
\hline
\end{tabular}

Results are mean of triplicate determinations \pm S.D Means within columns with different superscripts are significantly different (p < 0.05). ANS: acha native starch; ACAS: acid thinned acha starch; BAS: benzylatedacha starch; ATAS: acetylated acha starch; SAS: succinylatedacha starch; CAS: carboxymethylatedacha starch.

Table 2. Effect of temperature on swelling power of native and modified acha starches.

\begin{tabular}{ccccccc}
\hline Temp. ${ }^{\circ} \mathrm{C}$ & ANS & ATAS & BAS & CAS & SAS & ACAS \\
\hline $65^{\circ} \mathrm{C}$ & $11.65 \pm 0.01^{\mathrm{a}}$ & $11.75 \pm 0.03^{\mathrm{a}}$ & $11.82 \pm 0.02^{\mathrm{a}}$ & $11.18 \pm 0.01^{\mathrm{a}}$ & $11.84 \pm 0.04^{\mathrm{a}}$ & $2.15 \pm 0.02^{\mathrm{a}}$ \\
$75^{\circ} \mathrm{C}$ & $11.96 \pm 0.04^{\mathrm{b}}$ & $12.08 \pm 0.02^{\mathrm{b}}$ & $12.96 \pm 0.03^{\mathrm{c}}$ & $12.55 \pm 0.04^{\mathrm{b}}$ & $12.18 \pm 0.01^{\mathrm{b}}$ & $2.18 \pm 0.02^{\mathrm{b}}$ \\
$85^{\circ} \mathrm{C}$ & $12.05 \pm 0.02^{\mathrm{c}}$ & $12.25 \pm 0.02^{\mathrm{c}}$ & $12.88 \pm 0.02^{\mathrm{b}}$ & $12.96 \pm 0.02^{\mathrm{c}}$ & $12.33 \pm 0.02^{\mathrm{c}}$ & $2.44 \pm 0.01^{\mathrm{c}}$ \\
$95^{\circ} \mathrm{C}$ & $12.35 \pm 0.02^{\mathrm{d}}$ & & $12.68 \pm 0.02^{\mathrm{d}} 13.05 \pm 0.01^{\mathrm{d}} 13.01 \pm 0.02^{\mathrm{d}} 12.65 \pm 0.03^{\mathrm{d}} 2.48 \pm 0.01^{\mathrm{d}}$ & \\
\hline
\end{tabular}

Results are mean of triplicate determinations \pm S.D Means within columns with different superscripts are significantly different (p < 0.05$)$. ANS: acha native starch; ACAS: acid thinned acha starch; BAS: benzylatedacha starch; ATAS: acetylated acha starch; SAS: succinylatedacha starch; CAS: carboxymethylatedacha starch.

[31], which indicate that swelling power of enset starch increased as temperature increases.

Following a similar pattern with the swelling power, solubility of starches increased as temperature increased at all temperature studied (Table 3 ). The result showed that all forms of modifications reduced the solubility of native acha starch except in acid thinned starch. In a previous report, [3] had reported improved swelling power for Canavaliaensiformis starch following acetylation. Increases observed in the swelling power on chemical modification might be due to the weakening of the intragranular binding forces within the starch granule, which offered less restriction to swelling of the modified starches. Solubility increased as the temperature increased because of increase in mobility of the starch granules, which facilitated dispersion of starch molecules in water.

\subsection{Water and Oil Absorption Capacities}

Water and oil absorption capacities of chemically modified starches are presented in Table 4. The chemical modifications improved the water and oil absorption capacities as a result of incorporation of functional groups on the starch molecules which enhanced binding capacity more than the native starch while, acetylation did not improve water and oil absorption capacities. This agreed to the report of [20] that acetylation and oxidation do not improve water and oil absorption capacities of great northern bean starch.

Water and oil absorption capacities were higher following chemical modifications. Conversely, water and oil absorption capacities were lower in acid-thinned starch derivatives compared to native starch. This might be due to increase in starch crystallinity that probably restricted access of oil and water into the granules of the acid thinned starch. This result was in agreement with observations reported on the water and oil absorption capacities of modified bambara groundnut starch [30] and rice starch [32].

\subsection{Gelation Properties (Least Gelation Concentration)}

The gelation properties of native, acetylated, benzylated, carboxymethylated, succinylated and acid thinned starch are presented in Table 5. The lowest concentration for gelation of acha starch is $6 \% \mathrm{w} / \mathrm{v}$. This value was lower than $10 \%$ and $16 \%$ observed in BAS and ACAS. Bulky groups introduced during acetylation will minimize this interaction and caused electrostatic repulsion among the starch molecules thereby increasing LGC values.

\subsection{Alkaline Water Retention}

Alkaline water retention capacity of the native and chemically modified starches is presented in Table 6. It is a parameter that is related to cookie diameter [33]. Increase in alkaline water retention capacity was ob- 
Table 3. Effect of temperature on solubility of native and modified acha starches.

\begin{tabular}{cccccc}
\hline Temp. ${ }^{\circ} \mathrm{C}$ & ANS & ATAS & BAS & CAS & AAS \\
\hline $65^{\circ} \mathrm{C}$ & $10.25 \pm 0.01^{\mathrm{b}}$ & $9.66 \pm 0.03^{\mathrm{a}}$ & $5.37 \pm 0.02^{\mathrm{a}}$ & $9.11 \pm 0.01^{\mathrm{a}}$ & $9.05 \pm 0.04^{\mathrm{a}}$ \\
$75^{\circ} \mathrm{C}$ & $10.44 \pm 0.04^{\mathrm{c}}$ & $9.74 \pm 0.02^{\mathrm{b}}$ & $5.55 \pm 0.03^{\mathrm{b}}$ & $9.21 \pm 0.04^{\mathrm{b}}$ & $9.33 \pm 0.01^{\mathrm{b}}$ \\
$85^{\circ} \mathrm{C}$ & $10.73 \pm 0.02^{\mathrm{d}}$ & $9 . .84 \pm 0.02^{\mathrm{c}}$ & $5.77 \pm 0.02^{\mathrm{c}}$ & $9.46 \pm 0.02^{\mathrm{c}}$ & $9.62 \pm 0.02^{\mathrm{c}}$ \\
$95^{\circ} \mathrm{C}$ & $10.05 \pm 0.02^{\mathrm{a}}$ & & $11.36 \pm 0.02^{\mathrm{b}}$ & $11.65 \pm 0.01^{\mathrm{c}}$ & \\
\hline
\end{tabular}

Results are mean of triplicate determinations \pm S.D Means within columns with different superscripts are significantly different (p < 0.05). ANS: acha native starch; ACAS: acid thinned acha starch; BAS: benzylatedacha starch; ATAS: acetylated acha starch; SAS: succinylatedacha starch; CAS: carboxymethylatedacha starch.

Table 4. Water and oil absorption capacity of native and chemically modified acha starch.

\begin{tabular}{ccc}
\hline Samples & Water absorption capacity (\%) & Oil absorption capacity (g/g) \\
\hline ANS & 98.75 & 1.22 \\
ATAS & 63.22 & 1.16 \\
BAS & 99.85 & 1.22 \\
SAS & 94.58 & 1.26 \\
ACAS & 12.05 & 1.12 \\
\hline
\end{tabular}

Results are mean of triplicate determinations. ANS: acha native starch; ACAS: acid thinned acha starch; BAS: benzylatedacha starch; ATAS: acetylated acha starch; SAS: succinylatedacha starch; CAS: carboxymethylatedacha starch.

Table 5. Gelation capacity of native and modified acha starches.

\begin{tabular}{|c|c|c|c|c|c|c|}
\hline \multirow{2}{*}{ Sample concentration (\%) } & \multicolumn{6}{|c|}{ Starch samples } \\
\hline & ANS & ATAS & BAS & CAS & SAS & ACAS \\
\hline 2 & -Viscous & -Viscous & -Viscous & -Viscous & -Viscous & -Viscous \\
\hline 4 & -Viscous & -Viscous & -Viscous & -Viscous & -Viscous & -Viscous \\
\hline 6 & $+\mathrm{Gel}$ & $+\mathrm{Gel}$ & -Viscous & + Gel & + Gel & -Viscous \\
\hline 8 & $+\mathrm{Gel}$ & $+\mathrm{Gel}$ & -Viscous & $+\mathrm{Gel}$ & + Gel & -Viscous \\
\hline 10 & + Gel & $+\mathrm{Gel}$ & + Gel & $+\mathrm{Gel}$ & $+\mathrm{Gel}$ & -Viscous \\
\hline 12 & + Gel & $+\mathrm{Gel}$ & $+\mathrm{Gel}$ & $+\mathrm{Gel}$ & + Gel & -Viscous \\
\hline 14 & $+\mathrm{Gel}$ & $+\mathrm{Gel}$ & $+\mathrm{Gel}$ & $+\mathrm{Gel}$ & $+\mathrm{Gel}$ & -Viscous \\
\hline 16 & + Gel & $+\mathrm{Gel}$ & $+\mathrm{Gel}$ & $+\mathrm{Gel}$ & $+\mathrm{Gel}$ & + Gel \\
\hline LGC & 6 & 6 & 10 & 6 & 6 & 16 \\
\hline
\end{tabular}

Determination carried out in triplicates. (-) No gelation, $(+)$ gelation; LGC-Least Gelation Concentration.

Table 6. Alkaline water retention of native and chemically modified acha starches.

\begin{tabular}{cccccc}
\hline ANS & ATAS & BAS & CAS & SAS & ACAS \\
\hline $1.05 \pm 0.01^{\mathrm{a}}$ & $1.16 \pm 0.04^{\mathrm{b}}$ & $1.05 \pm 0.02^{\mathrm{a}}$ & $1.05 \pm 0.03^{\mathrm{a}}$ & $1.08 \pm 0.02^{\mathrm{a}}$ & $1.06 \pm 0.03^{\mathrm{a}}$ \\
\hline
\end{tabular}

Results are mean of triplicate determinations \pm S.D; Means within columns with different superscripts are significantly different (p $<0.05$ ).

served in some chemically modified starches such as ATAS, SAS and ACAS due to disintegration of the bonding forces within the starch granules, while other had the same value as the native starch. In a previous work [34] had earlier reported increased water retention capacity of wheat flour-starch blends. They partially attributed this increase in water absorption to the surface area of the starch phase and excessive dilution at high concentration of starch of the continuous gluten phase. This result shows that the starches can be used in cookiemaking.

\subsection{Pasting Properties of Native and Chemically Modified Acha Starches}

Pasting temperature of native and chemically modified starches is presented in Table 7. The pasting temperature 
Table 7. Pasting characteristics of native and chemically modified acha starches.

\begin{tabular}{ccccccc}
\hline Properties & Samples & & & & & \\
\hline & ANS & ATAS & BAS & CAS & SAS & ACAS \\
\hline Peak viscosity (Pv) & 300 & 474.50 & 194.25 & 236.83 & 322.66 & 1.67 \\
Trough & 98.33 & 286.33 & 60.25 & 99.33 & 160.58 & -4.33 \\
Breakdown (Pv-trough) & 202.58 & 188.17 & 134.00 & 137.50 & 162.08 & 6.00 \\
Final viscosity (Fv) & 244.25 & 392.17 & 137.33 & 137.42 & 299.42 & 0.00 \\
Setback (Fv-Pv) & 145.92 & 105.83 & 77.08 & 38.08 & 138.83 & 4.33 \\
Pasting temperature & 80.85 & 79.35 & 80.70 & 81.50 & 82.55 & 83.25 \\
\hline
\end{tabular}

is a measure of the temperature at which a starch starts to thicken. Pasting temperature increased in some chemically modified starches (CAS, SAS and ACAS) but slightly reduced in ATAS and BAS. Increase in pasting temperature after modification supports the fact that modification process tends to increase the region of crystallinity, as a result of reorientation of the starch granules. The strengthening of intragranular bonded forces, allows the starch to require more heat before structural disintegration and paste formation occurs $[35,36]$ had reported reduction in peak viscosity and hot paste viscosity after oxidation and acetylation and this agreed with our result. ATAS and SAS had higher peak viscosity than native starch, higher peak viscosity, which showed that they had more swelling power. Hot paste viscosity increased after modification in ATAS and SAS, while it was reduced in other modified starches. The increase in viscosity during cooling period is indicative not only of the normal inverse relationship between viscosity and temperature of the suspensions but also of the tendency for various constituents present in the hot paste (swollen granules, fragments of swollen granules and dissolved molecules) to associate or retrograde as the temperature of the paste decreases. Setback and breakdown values were significantly reduced after modification. Set back value is a measure of starch retrogradation tendency. Chemical modifications significantly reduced the setback value of the native starch due to introduction of acetyl, benzyl, carboxyl and succinyl groups. The associative tendency on cooling had been eliminated by the involvement of the hydroxyl groups on the starch molecules in the formation of hydrogen bonding during modification processes. The breakdown values (BD) of the starch also reduced after modification. It is a measure of the ease with which the swollen starch granule can be disintegrated, an indication of the degree of its organisation.

\section{Conclusion}

Starch obtained from acha was subjected to chemical modifications and some physicochemical properties of the starches determined. Temperature and $\mathrm{pH}$ had a pronounced effect on the swelling power and solubility of the starches. Chemical modifications enhanced water and oil absorption capacities of the starches. Increase in water absorption capacity enhances gel formation and gel strength which are desirable in food products like starchthickened sauces. Chemical modifications increased the pasting temperature of some modified starches, whereas peak viscosity, trough, setback and breakdown values all reduced after modifications. However, tendency for retrogradation reduced after modification as shown in setback values. This is an advantage in food products like bread which undergoes staling easily and in soups and sauces which undergo loss of viscosity and precipitation as a result of retrogradation.

\section{REFERENCES}

[1] D. A. Betancur-Ancona, E. Garcia-Cervesa, E. CanizaresHernandez and L. Chel-Guerrero, "Chemical Modification of Jack Bean (Caravaliaensiforonis) Starch by Succinylation,” Starch/Stärke, Vol. 54, 2002, pp. 540-546. http://dx.doi.org/10.1002/1521-379X(200211)54:11<540: :AID-STAR540>3.0.CO;2-\#

[2] S. Santacruz, K. Koch, E. Svensson, J. Raules and A. C. Eliasson, "Three Underutilized Sources of Starch from the Andean Region in Ecuador Part I. Physico-Chemical Characterization," Journal Carbohydrate Polymers, Vol. 49, No. 1, 2002, pp. 63-70. http://dx.doi.org/10.1016/S0144-8617(01)00305-8

[3] A. D. Betancur, A. C. Chel and H. E. Canizires, “Acetylation and Characterization of Canavalia ensiformis Starch," Journal of Agriculture and Food Chemistry, Vol. 45, No. 2, 1997, pp. 378-382. http://dx.doi.org/10.1021/jf960272e

[4] V. Singh and S. Z. Ali, "Acid Degradation of Starch, the Effect of Acid and Starch Type,” Carbohydrate Polymers, Vol. 41, No. 2, 2000, pp. 191-195. http://dx.doi.org/10.1016/S0144-8617(99)00086-7

[5] O. O. Olayinka, K. O. Adebowale and I. B. Olu-Owolabi, "Physicochemical Properties, Morphological and X-Ray Pattern of Chemically Modified White Sorghum Starch. 
(Bicolor-Moench)," Journal of Food Science and Technology, Vol. 50, No. 1, 2013, pp. 70-77. http://dx.doi.org/10.1007/s13197-011-0233-3

[6] D. A. V. Dendy, "Sorghum and Millets, Chemistry and Technology,” American Association of Cereal Chemists, St. Paul, 1995.

[7] NRC, “Grains. Fonio (Acha),” In: Lost Crops of Africa, Vol. 1, National Academy Press, National Research Council, Washington DC, 1996, pp. 59-75.

[8] H. Adoukonou-Sagbadja, A. Dansi, R. Vodouhe and K. Akpagana, "Collecting fonio (Digitariaexilis Kipp. Stapf, D. iburua Stapf), Landraces in Togo,” Plant Genet Resource Newsletter, Vol. 139, 2004, pp. 59-63.

[9] T. Philip and I. Itodo, “Acha (Digitaria spp.) a 'Ediscovered’ Indigenous Crops of West Africa Agricultural Engineering, International,” The CIGR E-Journal, Vol. VIII, 2006, pp. 1-9.

[10] A. I. Ayo and I. Nkama, “Acha (Digitaria exilis) in West Africa,” International Journal of Food Agriculture, Vol. 1, 2006, pp. 129-144.

[11] V. A. Jideani, R. Alamu and I. A. Jideani, "Preliminary Study into the Production of Non-Wheat Bread from Acha (Digitariaexilis)," Nutrition of Food Science, Vol. 37, No. 6, 2007, pp. 434-441. http://dx.doi.org/10.1108/00346650710838090

[12] V. A. Jideani, A. R. Salami and I. A. Jideani, "Effect of Irish Potato Starch, Yeast and Sprouted Soybean Flour on the Quality of Acha Bread,” British of Food Journal, Vol. 110, No. 3, 2008, pp. 271-282. http://dx.doi.org/10.1108/00070700810858682

[13] J. R. N. Taylor, “Traditional African Grains,” In: Traditional Grains for Low Environmental Impact and Good Health, Seminar/Workshop Organised by MISTRA and IFS, Gothenburg, 2008, pp. 24-27.

[14] H. O. Agu, I. A. Jideani and I. Z. Yusuf, "Storage Stability of Improved Dambu Produced from Different Cereal Grains,” Nutrition Food Science, Vol. 38, No. 5, 2008, pp. 458-472. http://dx.doi.org/10.1108/00346650810906985

[15] H. O. Agu, I. A. Jideani and J. U. Humphrey, "Quality of Dambu Prepared with Different Cereals and Groundnut," Journal of Food Science Technology, Vol. 46, No. 2, 2009, pp. 166-168.

[16] S. Dury, V. Meuriot, G. Fliedel, B. G. F. Blancher, D. Drame, N. Bricas L. Dialite and J. F. Cruz, "The Retail Market Prices of Fonio Reveal the Demand for Quality Characteristics in Bamako, Mali,” European Association of Agricultural Economists at 106th Seminar, Montpellier, 25-27 October 2007.

[17] I. A. Jideani, “Traditional and Possible Technological Uses of Digitariaexilis (acha) and Digitariaiburua (iburu), a Review," Plant Foods Human Nutrition, Vol. 54, No. 4, 1999, pp. 363-374. http://dx.doi.org/10.1108/00346650810906985

[18] N. Hag and F. D. Ogbe, “Fonio,” In: J. T. Williams, Ed., Cereal and Pseudocereals, Chapman and Hall, London, 1995, pp. 225-245.

[19] A.O.A.C., "Official Methods of Analysis,” 15th Edition,
Association of Official Analytical Chemists, Washington DC, 1996.

[20] S. K. Sathe and D. K. Salunkhe, "Isolation, Partial Characterization and Modification of the Great Northern Bean (Phaseolusvulgaris L.) Starch,” Journal of Food Science, Vol. 46, No. 2, 1981, pp. 617-621. http://dx.doi.org/10.1111/j.1365-2621.1981.tb04924.x

[21] R. J. Smith, "Characterization and Analysis of Starches," In: R. L. Whistler and E. F. Paschall, Eds., Starch: Chemistry and Technology (Vol. II), Academic Press, New York and London, 1967, pp. 620-625.

[22] P. C. Trubiano, "Succinate and Substituted Succinate Derivations of Starch," In: O. B. Wurzburg, Ed., Modified Starches: Properties and Uses, CRC Press, Roca Raton, 1986, pp. 131-148.

[23] M. W. Rutenberg and D. Solarek, "Starch Derivatives: Production and Use,” In: R. L. Whittler, J. W. Bemiller and E. F. Paschall, Eds., Starch: Chemistry and Technology, 2nd Edition, Academic Press, Orlando, 1984, pp. 311388.

http://dx.doi.org/10.1016/B978-0-12-746270-7.50016-1

[24] F. Berkhout and J. Guns, "Process for the Manufacture of Hydrophobiogranules Starch Ethers,” BPT. 1309321, 1973.

[25] M. I. Khalil, A. Hashem and A. Nebeish, "Carboxymethylation of Maize Starch,” Starch/Stärke, Vol. 42, No. 2, 1990, pp. 60-63. http://dx.doi.org/10.1002/star.19900420209

[26] K. O. Adebowale, I. B. Olu-Owolabi, O. O. Olayinka and O. S. Lawal, "Effect of Heat Moisture Treatment and Annealing on Physicochemical Properties of Red Sorghum Starch,” African Journal of Biotechnology, Vol. 4, No. 9, 2005, pp. 928-933.

[27] I. R. Beuchat, "Functional and Electrophoretic Characteristic of succinylated Peanut Flour Proteins," Journal of Agriculture and Food Chemistry, Vol. 25, No. 2, 1977, pp. 258-260. http://dx.doi.org/10.1021/jf60210a044

[28] S. K. Sathe, P. D. Rangnekar, S. S. Deshpande and D. K. Salunkhe, "Isolation, Partial Characterization of Black Gram (Phaseolusmungo L.) Starch,” Journal of Food Science, Vol. 47, No. 5, 1982, pp. 1524-1527. http://dx.doi.org/10.1111/j.1365-2621.1982.tb04974.x

[29] N. S. Sodhi and N. Singh, "Characteristic of Acetylated Starchesprepared Using Starches Separated from Different Rice Cultivars,” Journal Food Engineering, Vol. 70, No. 1, 2005, pp. 117-127. http://dx.doi.org/10.1016/j.jfoodeng.2004.09.018

[30] K. O. Adebowale, O. S. Lawal and A. T. Afolabi, "Isolation, Chemical, Modification and Physicochemical Characterization of Bambara Groundnut (Voandzeia Subterranean) Starch and Flow," Food Chemistry, Vol. 78, No. 3, 2002, pp. 305-311. http://dx.doi.org/10.1016/S0308-8146(02)00100-0

[31] R. Gebre-Mariam and P. C. Schmidt, "Isolation and Physicochemical Properties of Enset Starch,” Starch/Starke, Vol. 48, No. 6, 1996, pp. 208-214. http://dx.doi.org/10.1002/star.19960480603

[32] Z. Gonzalez and E. Perez, "Effects of Acetylation on 
Some Properties of Rice Starch,” Starch/Starke, Vol. 54, No. 3-4, 2002, pp. 148-154.

http://dx.doi.org/10.1002/1521-379X(200204)54:3/4<148 :AID-STAR148>3.0.CO;2-N

[33] W. T. Yamazaki, J. R. Donelson and W. F. Kwolek, "Effects of Flour Fraction on Cookie Diameter," Cereal Chemistry, Vol. 54, 1997, pp. 352-361.

[34] O. F. Rasper and J. M. Deman, "Measurement of Hydration Capacity of Wheat Flour/Starch Mixtures," Cereal Chemistry, Vol. 57, No. 1, 1980, pp. 227-231.
[35] A. C. Elliason, "Effect of Water Content on the Gelatinization of Wheat Starch," Starch/Starke, Vol. 32, No. 8, 1980, p. 327.

[36] N. Atichokudomchai, C. Shobsngob and S. Padvaravinit, "A Study of Some Physicochemical Properties of Highcrystalline Tapioca Starch,” Starch/Starke, Vol. 53, No. 11, 2001, pp. 577-581.

http://dx.doi.org/10.1002/1521-379X(200111)53:11<577: :AID-STAR577>3.0.CO;2-0 